\title{
Feeding the People: The Politics of the Potato. By Rebecca Earle. 2020. Cambridge University Press, Cambridge, United Kingdom. 306 pp.
}

\author{
Eugene N. Anderson ${ }^{1^{*}}$ \\ ${ }^{1}$ Department of Anthropology, University of California, Riverside, USA. \\ "gene@ucr.edu
}

Received January 1, 2021

OPEN Ә ACCESS

Accepted January 4, 2021

Published March 15, 2021

DOI 10.14237/ebl.12.1.2021.1745

\begin{abstract}
Copyright (c) 2021 by the author(s); licensee Society of Ethnobiology. This is an open-access article distributed under the terms of the Creative Commons Attribution-NonCommercial 4.0 International Public License (https://creativecommons.org/licenses/by-nc/4.0), which permits non-commercial use, distribution, and reproduction in any medium, provided the original author and source are credited.
\end{abstract}

The potato has inspired many books, this being the latest. Rebecca Earle, a British historian, focuses on the potato in English and worldwide political history. Earle begins with the origin and ancestry of the potato in the Andes. She quickly moves to its introduction to Europe. This involved early confusion with sweet potatoes and Jerusalem artichokes. Clearly such lack of differentiation is not entirely a thing of the past, since on page 32 she provides a very clear picture of a Jerusalem artichoke (from 1630) but identifies it as a sweet potato (the two plants look quite different). Here and throughout the book, Earle gives only brief discussions of the differences between white and sweet potatoes, and their very different biology and requirements.

She goes on to dismantle classic myths of the rejection of the potato in premodern Europe. It was only rarely and tentatively blamed for causing leprosy. It was not rejected for being unmentioned in the Bible, and neither were dozens of other crops not mentioned therein. It was not rejected for being in the family of deadly nightshade. (In fact, potato greens are poisonous, but that has never stopped anyone from eating the tubers.) It was, in fact, not rejected at all; it spread slowly, because of difficulties acclimatizing, but it was adopted locally in the sixteenth century and widely in the seventeenth century. This was well before the eighteenth century window when it became well known in elite literature. Peasants and free farmers were eagerly growing and eating potatoes; the rich were more conservative. Farmers found that potatoes are easy to grow, easy to hide (one can just leave them buried), hard for governments to store, and hard to tax (points made by James Scott [2018]). Landlords and, above all, taxdemanding governments worked to get farmers to grow grain rather than root crops.

From about this point, Earle increasingly focuses on the British Isles, especially England. She harks back to an older school of English historians, who wrote (and still write) books with very general titles and some worldwide coverage but actually focused tightly on their own country. Even a chapter on "Global Potatoes"- - which gets ahead of her story to bring China into the twentieth century-largely covers British Empire outposts.

By the eighteenth century, land and food were getting scarce in much of Europe, and the potato was seen as a godsend. Governments promoted it. Worthy benefactors created recipes for feeding armies on potato soup with bits of meat (see recipe, p. 89). She repeats the old story (from a contemporary source) of Parmentier popularizing the potato by having a royal garden of potatoes, guarded by gendarmes ordered to look the other way at night; of course, the potatoes were stolen as fast as the local farmers could dig, and were soon growing everywhere. She does not repeat the folktale about Catherine the Great of Russia popularizing potatoes by wearing a wreath of potato flowers in her hair. Either way, elite devices to popularize potatoes worked well, and the plant spread widely. Parenthetically, potatoes were also introduced about this time to the Northwest Coast of America by Spanish voyagers and by the late eighteenth century the Indigenous people there were selling them in quantity to sailing ships. Heirloom varieties have developed. In the Northwest, showing how fast and thoroughly potatoes get adopted even in rather 
unlikely settings; the Northwest Coast people had no previous agriculture, though they were "preadapted" by cultivating wild root crops.

Earle then shifts to more modern times. Before Malthus, European countries wanted to increase their populations, and the potato was a godsend. After Malthus, and not just because of his writings (anyone could see trouble building), concern for overpopulation grew, and the potato appeared more and more as a way of allowing too many people to live on too few resources. A family could survive on a fraction of an acre, living on a minimalist diet of potatoes and buttermilk, and could avoid raising grain too. Potato eaters were famed for poverty and want, as in Van Gogh's famous early painting (shown on p. 208). Workers rebelled against being forced to depend on the plant. Of course, Earle has to give some account of the Irish potato famine of 1846-1850, but keeps it rather brief, presumably because so many good books have been written about it (e.g., Woodham-Smith 1962). Like most writers, she barely mentions the fact that this famine also devastated Germany, Russia, and eastern Europe.

Meanwhile, the British Empire promoted potatogrowing from New Zealand (where the Maori already had sweet potatoes in abundance) to India and to America. Earle casts a cynical eye on this enterprise: "Such schemes were concerned far more with legitimating particular forms of governance than with reducing hunger. Britain's track record in hunger prevention in India [and elsewhere] was in fact extremely poor" (p. 114). Earle sees potato promotion abroad as largely a cold-blooded attempt to look virtuous while alienating food and other products from local populations. Without denying some reality to this image, one has to question the lack of any qualifications in Earle's narrative. Surely there were well-meaning potato introducers, and there most certainly were colonialists who did not make even the pretense of being moral about their work. This is the clearest case of Earle's tendency to ascribe a single, uniform mentality to everyone in a particular era, as if everyone rapidly came into perfect agreement.

Potatoes took on a virtuous mien again in World War I, and subsequently, as still-increasing populations became ever more dependent on them. In the twentieth century, potatoes have increasingly appeared essential to world food security with more and more effort devoted to breeding high-yield, disease-resistant forms. The Food and Agriculture
Organization (FAO) propagated them widely. Earle does not discuss the potato's role in the Green Revolution, which was more modest than that of the famous high-yield wheat and rice varieties, but was less subject to criticism for promoting industrial agriculture. The potato maintained its reputation as a smallholder, low-tech crop.

Outside her purview, also, are recent innovations in potato-growing: new and improved varieties and breeding methods (Stokstad 2019), potatoes with vitamin A value (Knapp 2008), and even tomatoes and other Solanaceae grafted onto potatoes to produce double-value crops (McCann 2020). The great center of potato diversity, including diversity of closely related species, is still the Andes, as well as Chiloe Island in Chile, where Mapuche descendants keep countless varieties alive. These centers remain sources of genes for resistance to disease and for better growth. I recall the late potato expert Hugh Iltis (personal communication) often advocating that farmers in the Andes be paid not to modernize. In fact, something like this is now being done, with many programs in the Andes and Chiloe Island to help local people save local varieties and to share at least a small bit of the enormous profits that are generated when genes go worldwide.

Among major earlier works on the potato in society, Redcliffe Salaman's (1985) classic The History and Social Influence of the Potato stands out. It is a far more ambitious work than Earle's, combining biology, history, economics, and social science with brilliant success. James Lang's (2001) Notes of a Potato Watcher adds personal research, while John Reader's (2008) Propitious Esculent more or less recaps Salaman and brings his book up to date.

Salaman's classic was the first of many books that thoughtfully explore the ramifications of a particular crop in world commerce, and especially the ways that unique biological qualities and unique world-economic situations interact to produce vast profits but also unexpected catastrophes. Sidney Mintz' (1985) famous work on sugar, Sweetness and Power, is probably the best -known of these. More specialized and thus less wellknown, but a superb work, is Sucheta Mazumdar's (1998) Sugar and Society in China. Sven Beckert's (2014) recent work Empire of Cotton, which I reviewed in Ethnobiology Letters (Anderson 2017), deserves equal fame with Salaman and Mintz. This work is now joined by Andrew Flachs' (2019) study of cotton in India, Cultivating Knowledge; some readers of this journal 
may recall that this book started life as Andy's prizewinning student paper at a Society of Ethnobiology meeting some years ago. Many more such books could be listed, covering everything from soybeans (Du Bois et al. 2008) to chiles, coffee, tea, chocolate, and other commercial plants.

Oddly enough, there are no comparable books on grain crops. Many technical books on wheat, rice, barley, oats, rye, millets, sorghum, and other grains are available, but there is not a single book on any grain comparable to Salaman, Mintz, or Beckert. Maize is a partial exception, with good books including Betty Fussell's (1992) The Story of Corn, but more is needed. If I were starting on my career now, I would certainly devote a considerable part of my life to researching a grain, preferably wheat, and writing a major biography of it. I strongly recommend such activity to aspiring ethnobotanists.

\section{References Cited}

Anderson, E. N. 2017. Empire of Cotton: A Global History. By Sven Beckert. 2014. Vintage, New York, NY. 615 pp. Ethnobiology Letters 8:97-100. DOI:10.14237/ebl.8.1.2017.1068.

Beckert, S. 2014. Empire of Cotton: A Global History. Vintage, New York.

Du Bois, C. M., T. Chee-Beng, S. Mintz, eds. 2008. The World of Soy. University of Illinois Press, Urbana, IL.

Flachs, A. 2019. Cultivating Knowledge: Biotechnology, Sustainability, and the Human Cost of Cotton Capitalism in India. University of Arizona Press, Tucson, AZ.
Fussell, B. 1992. The Story of Corn. Knopf, New York.

Knapp, S. 2008. Celebrating Spuds. Science 321:206207. DOI:10.1126/science.1159278.

Lang, J. 2001. Notes of a Potato Watcher. Texas A \& M Press, College Station, TX.

Mazumdar, S. 1998. Sugar and Society in China: Peasants, Technology, and the World Market. Harvard University Press, Cambridge, MA.

McCann, M. C. 2020. Chimeric Plants-the Best of Both Worlds. Science 369:618-619. DOI:10.1126/ science.abd1641.

Mintz, S. W. 1985. Sweetness and Power: The Place of Sugar in Modern History. Penguin Books, New York.

Reader, J. 2008. Propitious Esculent: The Potato in World History. William Heinemann, London.

Salaman, R. 1985. The History and Social Influence of the Potato, $2^{\text {nd }}$ edition, edited by J. Hawkes. Cambridge University Press, Cambridge, United Kingdom.

Scott, J. C. 2018. Against the Grain: A Deep History of the Earliest States. Yale University Press, New Haven, CT.

Stokstad, E. 2019. The New Potato. Science 363:574577. DOI:10.1126/science.363.6427.574.

Woodham-Smith, C. 1962. The Great Hunger. Harper and Row, New York. 